

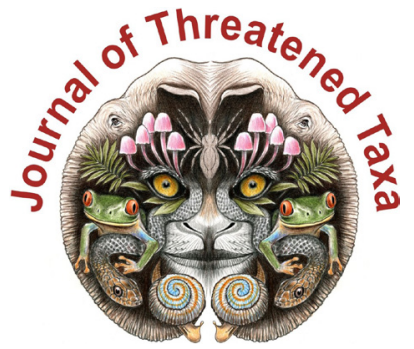

ISSN 0974-7907 (Online); ISSN $0974-7893$ (Print)

Publisher

Host

Wildlife Information Liaison Development Society

www.wild.zooreach.org

Zoo Outreach Organization www.zooreach.org

No. 12, Thiruvannamalai Nagar, Saravanampatti - Kalapatti Road, Saravanampatti, Coimbatore, Tamil Nadu 641035, India

Ph: +91 9385339863 | www.threatenedtaxa.org

Email: sanjay@threatenedtaxa.org

EDITORS

\section{Founder \& Chief Editor}

Dr. Sanjay Molur

Wildlife Information Liaison Development (WILD) Society \& Zoo Outreach Organization (ZOO),

12 Thiruvannamalai Nagar, Saravanampatti, Coimbatore, Tamil Nadu 641035, India

\section{Deputy Chief Editor}

Dr. Neelesh Dahanukar

Noida, Uttar Pradesh, India

\section{Managing Editor}

Mr. B. Ravichandran, WILD/ZOO, Coimbatore, India

\section{Associate Editors}

Dr. Mandar Paingankar, Government Science College Gadchiroli, Maharashtra 442605, India

Dr. Ulrike Streicher, Wildlife Veterinarian, Eugene, Oregon, USA

Ms. Priyanka Iyer, ZOO/WILD, Coimbatore, Tamil Nadu 641035, India

Dr. B.A. Daniel, ZOO/WILD, Coimbatore, Tamil Nadu 641035, India

\section{Editorial Board}

Dr. Russel Mittermeier

Executive Vice Chair, Conservation International, Arlington, Virginia 22202, USA

\section{Prof. Mewa Singh Ph.D., FASc, FNA, FNASc, FNAPsy}

Ramanna Fellow and Life-Long Distinguished Professor, Biopsychology Laboratory, and Institute of Excellence, University of Mysore, Mysuru, Karnataka 570006, India; Honorary Professor, Jawaharlal Nehru Centre for Advanced Scientific Research, Bangalore; and Adjunct Professor, National Institute of Advanced Studies, Bangalore

\section{Stephen D. Nash}

Scientific Illustrator, Conservation International, Dept. of Anatomical Sciences, Health Sciences Center, T-8, Room 045, Stony Brook University, Stony Brook, NY 11794-8081, USA

\section{Dr. Fred Pluthero}

Toronto, Canada

\section{Dr. Priya Davidar}

Sigur Nature Trust, Chadapatti, Mavinhalla PO, Nilgiris, Tamil Nadu 643223, India

\section{Dr. Martin Fisher}

Senior Associate Professor, Battcock Centre for Experimental Astrophysics, Cavendish

Laboratory, JJ Thomson Avenue, Cambridge CB3 OHE, UK

\section{Dr. John Fellowes}

Honorary Assistant Professor, The Kadoorie Institute, 8/F, T.T. Tsui Building, The University of Hong Kong, Pokfulam Road, Hong Kong

\section{Prof. Dr. Mirco Solé}

Universidade Estadual de Santa Cruz, Departamento de Ciências Biológicas, Vice-coordenado do Programa de Pós-Graduação em Zoologia, Rodovia Ilhéus/Itabuna, Km 16 (45662-000)

Salobrinho, Ilhéus - Bahia - Brasil

\section{Dr. Rajeev Raghavan}

Professor of Taxonomy, Kerala University of Fisheries \& Ocean Studies, Kochi, Kerala, India

\section{English Editors}

Mrs. Mira Bhojwani, Pune, India

Dr. Fred Pluthero, Toronto, Canad

Mr. P. Ilangovan, Chennai, India

Web Development

Mrs. Latha G. Ravikumar, ZOO/WILD, Coimbatore, India

\section{Typesetting}

Mr. Arul Jagadish, ZOO, Coimbatore, India

Mrs. Radhika, ZOO, Coimbatore, India

Mrs. Geetha, ZOO, Coimbatore India
Fundraising/Communications

Mrs. Payal B. Molur, Coimbatore, India

Subject Editors 2018-2020

Fungi

Dr. B. Shivaraju, Bengaluru, Karnataka, India

Dr. R.K. Verma, Tropical Forest Research Institute, Jabalpur, India

Dr. Vatsavaya S. Raju, Kakatiay University, Warangal, Andhra Pradesh, India

Dr. M. Krishnappa, Jnana Sahyadri, Kuvempu University, Shimoga, Karnataka, India

Dr. K.R. Sridhar, Mangalore University, Mangalagangotri, Mangalore, Karnataka, India

Dr. Gunjan Biswas, Vidyasagar University, Midnapore, West Bengal, India

\section{Plants}

Dr. G.P. Sinha, Botanical Survey of India, Allahabad, India

Dr. N.P. Balakrishnan, Ret. Joint Director, BSI, Coimbatore, India

Dr. Shonil Bhagwat, Open University and University of Oxford, UK

Prof. D.J. Bhat, Retd. Professor, Goa University, Goa, India

Dr. Ferdinando Boero, Università del Salento, Lecce, Italy

Dr. Dale R. Calder, Royal Ontaro Museum, Toronto, Ontario, Canada

Dr. Cleofas Cervancia, Univ. of Philippines Los Baños College Laguna, Philippines

Dr. F.B. Vincent Florens, University of Mauritius, Mauritius

Dr. Merlin Franco, Curtin University, Malaysia

Dr. V. Irudayaraj, St. Xavier's College, Palayamkottai, Tamil Nadu, India

Dr. B.S. Kholia, Botanical Survey of India, Gangtok, Sikkim, India

Dr. Pankaj Kumar, Kadoorie Farm and Botanic Garden Corporation, Hong Kong S.A.R., China

Dr. V. Sampath Kumar, Botanical Survey of India, Howrah, West Bengal, India

Dr. A.J. Solomon Raju, Andhra University, Visakhapatnam, India

Dr. Vijayasankar Raman, University of Mississippi, USA

Dr. B. Ravi Prasad Rao, Sri Krishnadevaraya University, Anantpur, India

Dr. K. Ravikumar, FRLHT, Bengaluru, Karnataka, India

Dr. Aparna Watve, Pune, Maharashtra, India

Dr. Qiang Liu, Xishuangbanna Tropical Botanical Garden, Yunnan, China

Dr. Noor Azhar Mohamed Shazili, Universiti Malaysia Terengganu, Kuala Terengganu, Malaysia

Dr. M.K. Vasudeva Rao, Shiv Ranjani Housing Society, Pune, Maharashtra, India

Prof. A.J. Solomon Raju, Andhra University, Visakhapatnam, India

Dr. Mandar Datar, Agharkar Research Institute, Pune, Maharashtra, India

Dr. M.K. Janarthanam, Goa University, Goa, India

Dr. K. Karthigeyan, Botanical Survey of India, India

Dr. Errol Vela, University of Montpellier, Montpellier, France

Dr. P. Lakshminarasimhan, Botanical Survey of India, Howrah, India

Dr. Larry R. Noblick, Montgomery Botanical Center, Miami, USA

Dr. K. Haridasan, Pallavur, Palakkad District, Kerala, India

Dr. Analinda Manila-Fajard, University of the Philippines Los Banos, Laguna, Philippines

Dr. P.A. Sinu, Central University of Kerala, Kasaragod, Kerala, India

Dr. Afroz Alam, Banasthali Vidyapith (accredited A grade by NAAC), Rajasthan, India

Dr. K.P. Rajesh, Zamorin's Guruvayurappan College, GA College PO, Kozhikode, Kerala, India

Dr. David E. Boufford, Harvard University Herbaria, Cambridge, MA 02138-2020, USA

Dr. Ritesh Kumar Choudhary, Agharkar Research Institute, Pune, Maharashtra, India

Dr. Navendu Page, Wildlife Institute of India, Chandrabani, Dehradun, Uttarakhand, India

\section{Invertebrates}

Dr. R.K. Avasthi, Rohtak University, Haryana, India

Dr. D.B. Bastawade, Maharashtra, India

Dr. Partha Pratim Bhattacharjee, Tripura University, Suryamaninagar, India

Dr. Kailash Chandra, Zoological Survey of India, Jabalpur, Madhya Pradesh, India

Dr. Ansie Dippenaar-Schoeman, University of Pretoria, Queenswood, South Africa

Dr. Rory Dow, National Museum of natural History Naturalis, The Netherlands

Dr. Brian Fisher, California Academy of Sciences, USA

Dr. Richard Gallon, llandudno, North Wales, LL30 1UP

Dr. Hemant V. Ghate, Modern College, Pune, India

Dr. M. Monwar Hossain, Jahangirnagar University, Dhaka, Bangladesh

Mr. Jatishwor Singh Irungbam, Biology Centre CAS, Branišovská, Czech Republic.

Dr. Ian J. Kitching, Natural History Museum, Cromwell Road, UK

Dr. George Mathew, Kerala Forest Research Institute, Peechi, India

For Focus, Scope, Aims, and Policies, visit https://threatenedtaxa.org/index.php/JoTT/aims_scope
For Article Submission Guidelines, visit https://threatenedtaxa.org/index.php/JoTT/about/submissions
For Policies against Scientific Misconduct, visit https://threatenedtaxa.org/index.php/JoTT/policies_various

continued on the back inside cover 


\title{
Recovery of vulture population in roosting and scavenging areas of Bastar and Bijapur, Chhattisgarh, India
}

\author{
Sushil Kumar Dutta ${ }^{1}$ (D), Muntaz Khan ${ }^{2}$ (D), P.R.S. Nagi ${ }^{3}$ (D), Santosh Durgam ${ }^{4}$ (D) \& Surabhi Dutta ${ }^{5}$ (D) \\ ${ }^{1,4}$ Department of Zoology, Govt. P.G. College, Jagdalpur, Bastar, Chhattisgarh 494001, India. \\ ${ }^{2}$ Department of Zoology, Kalahandi University, Bhawanipatna, Kalahandi, Odisha 766001, India. \\ ${ }^{3}$ Veterinary Hospital-Bastar, Bastar, Chhattisgarh 494223, India. \\ ${ }^{5}$ Institute for Excellence in Higher Education, Bhopal, Madhya Pradesh 462016, India. \\ ${ }^{1}$ dutta.sushil1962@gmail.com (corresponding author), ${ }^{2}$ soneyal@yahoo.co.in, ${ }^{3}$ prsn67@gmail.com, ${ }^{4}$ santoshdurgam1996@gmail.com,
} ${ }^{5}$ dutta.surabhisur@gmail.com

\begin{abstract}
Chhattisgarh is home to seven of the nine vulture species in India. One reason for this high vulture diversity is the presence of large herds of bovines numbering over 11 million individuals (ratio of human to bovine population is approximately 0.38 ), from which carcasses are disposed off in the open for scavengers. The late 1990s saw large scale decimation of vulture population, and since then there have been few studies with no sighting estimates available. In this study, concurrent sighting records were collected from different locations of southern Chhattisgarh and corroborated to develop conservative sighting estimates for sympatric populations of Gyps bengalensis and Gyps indicus. We present the first report on population recovery, with an estimated 30-35 Gyps bengalensis \& 20-25 Gyps indicus in/ around Rudraram of Bijapur and 18 Gyps bengalensis \& five Gyps indicus at Jamguda village of Bastar. Krishna Swami Gutta hill is identified as a nesting-roosting habitat for both species, for which six scavenging areas were identified in Bastar and Bijapur districts. The human/bovine population ratio for Bastar is 0.4 , similar to the state ratio, while in Bijapur the ratio is 1.07 , which justifies considering Bijapur as a conservation refuge. The few vultures that survived the diclofenac catastrophe in wild habitats most likely consumed wildlife carcasses that sustained a residual population. In these areas, the age-old practise of disposing off dead domesticated bovines away from settlements near reserve forests may also have supported the recovery of vulture population.
\end{abstract}

Keywords: Bovines, concurrent, diclofenac, diversity, Gyps bengalensis, Gyps indicus, habitat, nesting-roosting, sighting, sympatric.

Citation: Dutta, S.K., M. Khan, P.R.S. Nagi, S. Durgam \& S. Dutta (2021). Recovery of vulture population in roosting and scavenging areas of Bastar and Bijapur, Chhattisgarh, India. Journal of Threatened Taxa 13(13): 19956-19963. https://doi.org/10.11609/jott.7446.13.13.19956-19963

Copyright: @ Dutta et al. 2021. Creative Commons Attribution 4.0 International License. JoTT allows unrestricted use, reproduction, and distribution of this article in any medium by providing adequate credit to the author(s) and the source of publication.

Funding: No funding was availed for this study and publication from any funding agency/ies.

Competing interests: The authors declare no competing interests.

Author details: See end of this article.

Author contributions: SKD-supervised the study, identification of roosting and scavenging areas of vultures, conducted the vulture enumeration survey, collected information on daily movement of vultures from various sources, photographic documentation, compilation of data and drafted the research paper. MK-formulated the survey plan, protocols, participated in the survey, correlated information on vulture and habitat, analysis-interpretation of research data and finalized the research paper. PRSN-participated in the survey, photographic documentation, studied the bovine carrion in the study area and gave vital inputs for this research paper. SaD-MSc student participated in the survey to collect information on vultures from his designated survey site, photographic documentation and enumerated vulture numbers. SuD-graduate student participated in the survey and collected information on vulture from her designated survey site and enumerated vulture numbers.

Acknowledgements: Authors would like to acknowledge their respective affiliated institutions and Heads for encouragement during this research work. Authors are grateful for the help and information on vulture movements by Forest Officials of Indravati Tiger Reserve, Bijapur. Special thanks to anonymous reviewers and editor for giving valuable inputs.
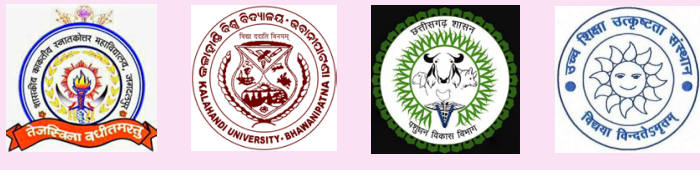


\section{INTRODUCTION}

Chhattisgarh is a land of dense forests, hill ranges, valleys, sheer cliffs, vast grasslands, agricultural land, waterfalls, and water-bodies. The estimated human population was 29 million for 2020 (Unique Identification Aadhar India updated 31 May 2019), with a rural population of about 22 million (i.e., $77 \%$ ). People generally maintain large herds of bovines totalling over 11 million animals (Livestock Census 2019) for agriculture and milk. The ratio of human to bovine population for Chhattisgarh state is approximately 0.38. Cattle are maintained largely on grazing, with basic shelters at night. Bovine death rates are relatively high owing to various factors. Many domestic bovines turn feral and enter forests, there are occasional outbreaks of disease since widespread vaccination is impractical, there are few veterinary personnel, many people prefer cheap traditional treatments over modern drugs, and most villages are far from the reach of emergency veterinary help. Dead animals are disposed off in a designated communal place on the outskirts of Bastar and Bijapur villages, where scavengers including vultures, feral carnivores and crows congregate.

Of the 22 vulture species worldwide, nine are resident to India, and seven - Indian Scavenger Vulture Neophron percnopterus ginginianus Latham, 1790; Oriental White backed Vulture Gyps bengalensis Gmelin, 1788; Indian Long-billed Vulture Gyps indicus Scopoli, 1786; Indian Griffon Vulture Gyps fulvus fulvescens Hume, 1869; Cinereous Vulture Aegypius monachus Linnaeus, 1766; and Black or King Vulture Sarcogyps calvus Scopoli, 1786-have been reported from Chhattisgarh (Ghosh et al. 2008). Information on vulture population and diversity for Chhattisgarh is scant from the southern part of the state.

Before the introduction of diclofenac (an antiinflammatory drug) in India during the 1990s vultures were recorded in large groups and were common sight in many localities, but the following years witnessed a continuous and drastic decline in vulture populations (Prakash et al. 2003). In 2004, Dr. Lindsay Oaks and his team found that diclofenac causes fatal renal failure in vultures. A simulation model demonstrated that if only $1 \%$ of the carcasses were contaminated by diclofenac, Indian vulture populations could decline 60-90\% annually, and it was reported that $10 \%$ of carcasses in India were contaminated (Green et al. 2004). In 2006, the Government of India banned the manufacture, marketing and use of diclofenac. Following this ban, the declining population of Gyps bengalensis slowed, but infrequent use of diclofenac continued (Prakash et al. 2012). Populations of White-rumped Vulture, Longbilled Vulture, and Slender-billed Vulture crashed during the mid-1990s throughout the Indian subcontinent, and the International Union for Conservation of Nature (IUCN) listed all of these species as 'Critically Endangered' (Birdlife International 2021). This study estimates vulture population in Bastar and Bijapur district of Chhattisgarh and attempts to correlate contributory factors for recovery post the decimation of the mid-1990s.

The White-rumped Vulture is identifiable by a conspicuous white ruff at base of neck, white inner thighs, a prominent broad white band on under-wings and 12 tail feathers. Head and neck are destitute of feathers and tinged pink, and the bill is dark at the tip and paler at the base with dark ceres. The nostril openings are slit-like. In flight, the white under-wing coverts are highly visible. The Long-billed Vultures is characterized by a narrow elongated head, long naked neck and head covered with woolly down sporting a prominent lanceolate ruff of feathers (longer in juvenile) at base of neck, and a long yellowish bill. It sports 14 tail feathers. The upper wings are sandy brown and darker head, have a buff ruff at the back of neck, feathers of back are sepia brown. Gyps indicus is smaller in size than Gyps bengalesis. Both are sociable, nest and roost communally on trees and cliffs (Grimmett et al. 2011; Naroji 2011). Both the species are medium-sized Old World vultures. White-rumped Vulture is native to southern and southeastern Asia. Long-billed Vulture is native to southern Asia.

\section{MATERIALS AND METHODS}

Opportunistic documentation of vultures in 20112016 gave the impetus to undertake dedicated surveys from June to October 2020, and in January 2021 in Bastar and Bijapur district of Chhattisgarh. Garmin GPSMap 78s was used to record the sighting position, Nikon Aculon A211 10-22 X 50 binoculars were used for spotting and identification of species. A Canon EOS 70D with an EF300mm f/4L IS USM lens and extender EF 1.4 X III were used for photographic documentation. The surveys were conducted in designated dead animal disposal places near villages. Concurrent sighting information was collected from different locations and corroborated to evolve conservative sighting estimates for vultures.

\section{Study area}

Two southern districts of Chhattisgarh; i.e., Bastar and Bijapur were covered to record the population of 


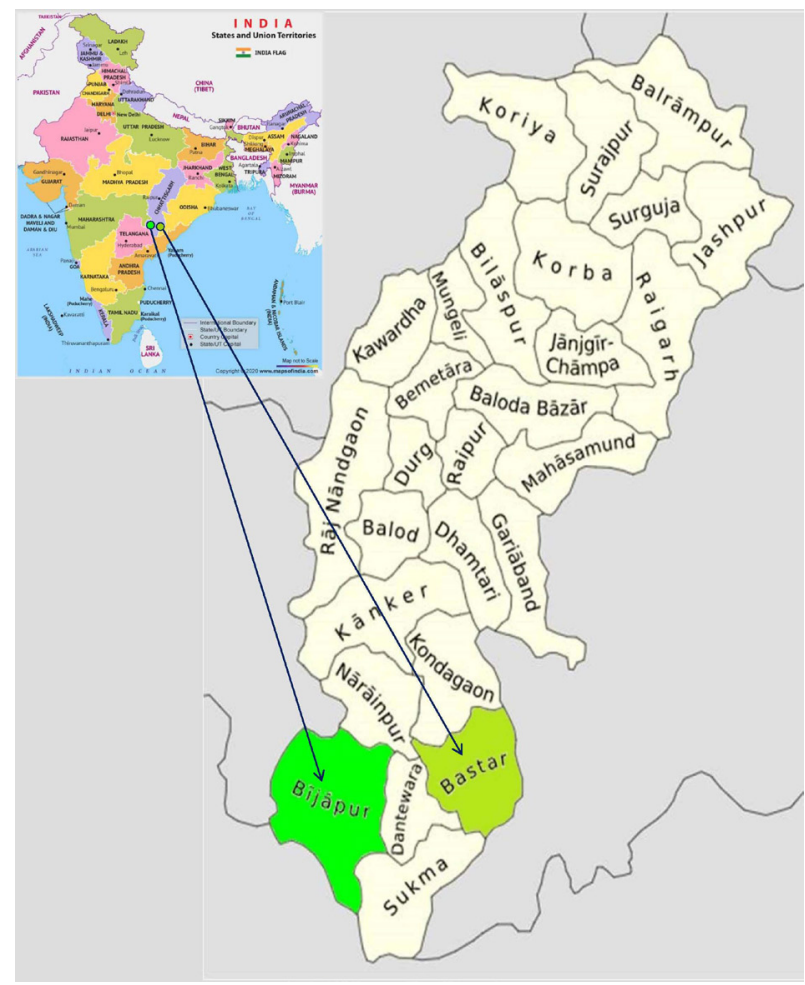

Figure 1. Outline map of Chhattisgarh districts with study area of vultures shaded green (Source: Wikipedia)

vultures (Figure 1). Bastar district covers an area of $6,596.90 \mathrm{~km}^{2}$. The district is bounded on east by Odisha, north by Kondagaon district, west by Narayanpur and Dantewada, and south by Sukma. It is situated at a height of $606 \mathrm{~m}$ plateau from sea level. Kanger Ghati National Park (also called Kanger Valley National Park) is a protected area in the Bastar district of Chhattisgarh.

Bijapur district covers an area of $6562.48 \mathrm{~km}^{2}$. The district is bounded on east by Dantewada and Sukma districts, north by Narayanpur district and Maharashtra, west by Maharashtra and south by Telangana. The major river is Indravati and flows through Bastar, Dantewada and Bijapur uniting with Godavari near Bhadrakali River. The district is a rocky hilly terrain with an altitude ranging 177-599 m. District is covered by rich and thick dense mixed forest interspersed by moist and intermediated forest with diverse forest species. Indravati Tiger Reserve (Biosphere reserve), lies within this district with high and rocky hills.

\section{OBSERVATION}

\section{Sightings of vultures in Bastar}

Bastar district has a human population of 0.83 million as per 2011 census, and more than $70 \%$ are tribal. The domesticated livestock population (cows and buffalos) is 0.34 million as per the $20^{\text {th }}$ Livestock Census, 2019. The ratio of human population to cattle population for Bastar district is approximately 0.4. Bastar district is covered with very and moderate dense forest of $3072.34 \mathrm{~km}^{2}$ or $47 \%$ (Indian State of Forest Report 2019).

The first and third author sighted 18 Gyps bengalensis and five Gyps indicus at Jamguda village of Bastar district in 2011 during post-mortem of 12 bovines succumbed to sudden death, and second sighting of one individual vulture gliding and soaring was recorded during 2015. Vultures sighted in Bastar are both resident and migrant. Sporadic records are available of their earlier sightings with no estimates of vultures.

\section{Sightings of vultures in Bijapur}

Bijapur district has human population of 0.26 million (2011 census), and more than $70 \%$ are tribal. The domesticated livestock population (cows and buffalos) is 0.28 million as per the $20^{\text {th }}$ Livestock Census, 2019. The ratio of human population to cattle population for Bastar district is approximately 1 . Moderate/dense forest cover is $4,975 \mathrm{~km}^{2}$ or $76 \%$ (Indian State of Forest Report 2019). Frequent and regular sightings of White-Rumped Vulture and Indian Vulture have been made in this area.

\section{Occasional Sightings of vultures in Dantewada}

On 04 February 2020, one migrating sub-adult Himalayan Griffon found in Geedam $\left(18.974^{\circ} \mathrm{N}\right.$, $81.399^{\circ} \mathrm{E}$ ), a village in Dantewada district. A group of crows attacked the vulture which succumbed to injuries even after its treatment in the zoo.

Table 1 presents chronological sighting records of vultures in Bastar and Bijapur (Image 4-8). Image 1, is GoogleEarth Map showing the sighting locations of Gyps bengalensis and Gyps indicus in Bastar and Bijapur districts. Figure 2, is a graphical presentation of vulture population in various roosting and scavenging sites.

\section{DISCUSSION}

Informal interviews with forest department personnel and local people of rural villages near Rudraram and Cherpalli revealed that vultures nest on Krishna Swami Gutta hill on the plain between the cliffs, 30-50 m above ground level. The hill is located south of Cherpalli in Bijapur district. Consistent sightings of vultures were documented in Bijapur district from March 2016, with photographic documentation and GPS co-ordinates. 
Table 1. Chronological sighting record of vultures in Bastar and Bijapur.

\begin{tabular}{|c|c|c|c|c|c|c|}
\hline \multirow{2}{*}{ Date } & \multirow[t]{2}{*}{ Time } & \multirow{2}{*}{ District } & \multirow{2}{*}{ Location } & \multicolumn{2}{|c|}{$\begin{array}{c}\text { Species wise number of } \\
\text { individuals }\end{array}$} & \multirow{2}{*}{$\begin{array}{l}\text { Position } \\
\text { Landed / perched / } \\
\text { gliding / soaring }\end{array}$} \\
\hline & & & & $\begin{array}{c}\text { Gyps } \\
\text { bengalensis }\end{array}$ & Gyps indicus & \\
\hline 31 Jul 2011 & 1208 & Bastar & $\begin{array}{l}\text { Jamguda village } \\
19.30333^{\circ} \mathrm{N} \\
81.96555^{\circ} \mathrm{E} \\
\end{array}$ & 18 & 5 & $\begin{array}{l}\text { Landed } \\
\text { Perched }\end{array}$ \\
\hline ?? 2015 & 1545 & Bastar & Bastar village & 1 & 0 & Gliding and soaring \\
\hline 05 Mar 2016 & 1142 & Bijapur & $\begin{array}{l}\text { Cherpalli } \\
18.83246^{\circ} \mathrm{N} \\
80.43249^{\circ} \mathrm{E}\end{array}$ & 4 & 0 & Gliding and soaring \\
\hline 06 Jun 2020 & 1128 & Bijapur & $\begin{array}{l}\text { Indravati } \\
\text { Tiger Reserve, } \\
18.81324^{\circ} \mathrm{N} \\
80.47578^{\circ} \mathrm{E}\end{array}$ & 13 & 12 & Landed \\
\hline 12 Jun 2020 & $\begin{array}{l}1103 \\
1630 \\
\end{array}$ & Bijapur & $\begin{array}{l}\text { Rudraram } \\
18.83700^{\circ} \mathrm{N} \\
80.41471^{\circ} \mathrm{E} \\
\end{array}$ & $\begin{array}{c}30-35 \\
3-4 \\
\end{array}$ & $\begin{array}{c}20-25 \\
1-2 \\
\end{array}$ & $\begin{array}{l}\text { Landed } \\
\text { Perched }\end{array}$ \\
\hline 13 Jun 2020 & 1115 & Bijapur & $\begin{array}{l}\text { Rudraram } \\
18.83702^{\circ} \mathrm{N} \\
80.41475^{\circ} \mathrm{E} \\
\end{array}$ & $18-20$ & $15-17$ & Landed \\
\hline 14 Jun 2020 & 1600 & Bijapur & $\begin{array}{l}\text { Rudraram } \\
18.83758^{\circ} \mathrm{N} \\
80.41465^{\circ} \mathrm{E} \\
\end{array}$ & $4-5$ & 2 & Gliding and soaring \\
\hline 30 Jun 2020 & 1428 & Bijapur & $\begin{array}{l}\text { Krishna Swami } \\
\text { Gutta hill } \\
18.79739^{\circ} \mathrm{N} \\
80.41125^{\circ} \mathrm{E}\end{array}$ & $6-7$ & 3 & Gliding and soaring \\
\hline 22 Jul 2020 & 0921 & Bijapur & $\begin{array}{l}\text { Rudraram } \\
18.83681^{\circ} \mathrm{N} \\
80.41521^{\circ} \mathrm{E} \\
\end{array}$ & 2 & 0 & Landed \\
\hline 24 Aug 2020 & 1122 & Bijapur & $\begin{array}{l}\text { Rudraram } \\
18.83695^{\circ} \mathrm{N} \\
80.41392^{\circ} \mathrm{E} \\
\end{array}$ & 10-12 & 0 & Landed and perched \\
\hline 03 Sep 2020 & 0928 & Bijapur & $\begin{array}{l}\text { Rudraram } \\
18.83682^{\circ} \mathrm{N} \\
80.41521^{\circ} \mathrm{E} \\
\end{array}$ & $30-31$ & $18-20$ & Landed \\
\hline 01 Oct 2020 & 1015 & Bijapur & $\begin{array}{l}\text { Rudraram } \\
18.83711^{\circ} \mathrm{N} \\
80.41482^{\circ} \mathrm{E}\end{array}$ & 17-19 & $10-12$ & Landed \\
\hline $12 \operatorname{Jan} 2021$ & 1000 & Bijapur & $\begin{array}{l}\text { Rudraram } \\
18.83711^{\circ} \mathrm{N} \\
80.41482^{\circ} \mathrm{E}\end{array}$ & 13 & 4 & $\begin{array}{l}\text { Landed } \\
\text { Perched }\end{array}$ \\
\hline
\end{tabular}

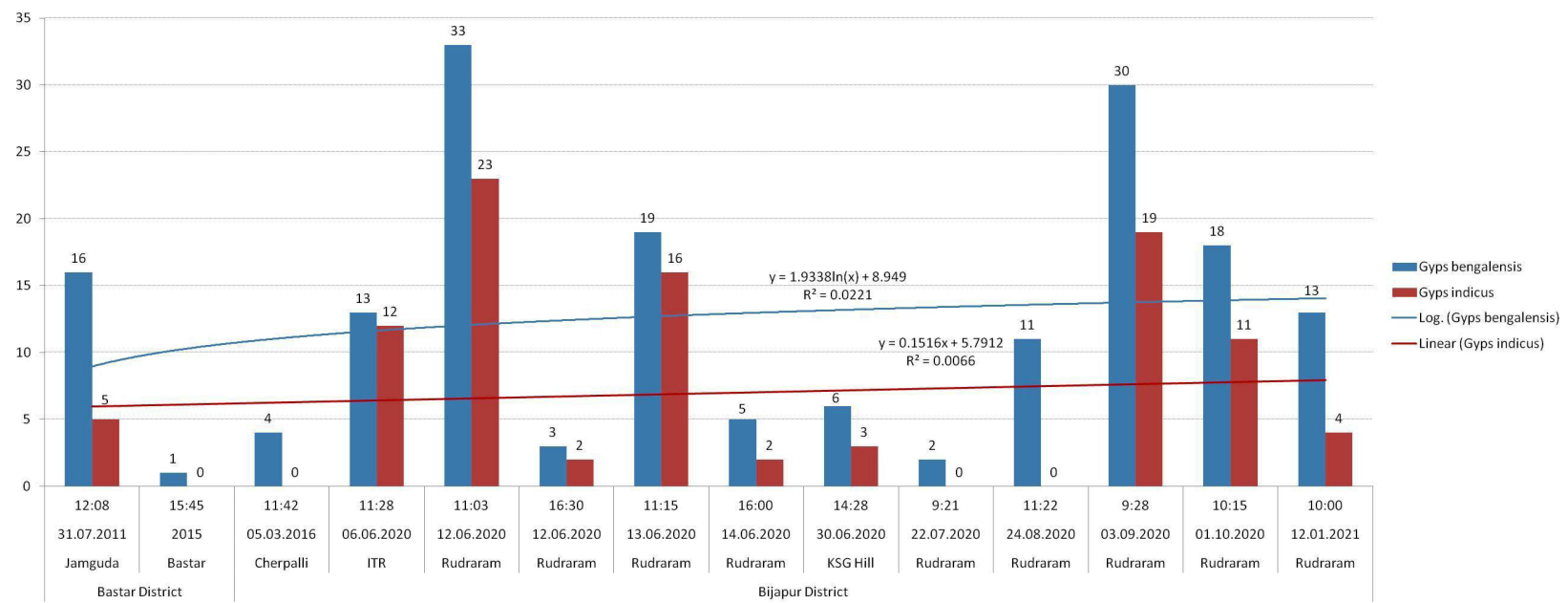

Figure 2. Graph represents vulture population in scavenging and roosting sites of southern Chhattisgarh (ITR - Indravati Tiger Reserve, KSG hill - Krishna Swami Gutta hill). 


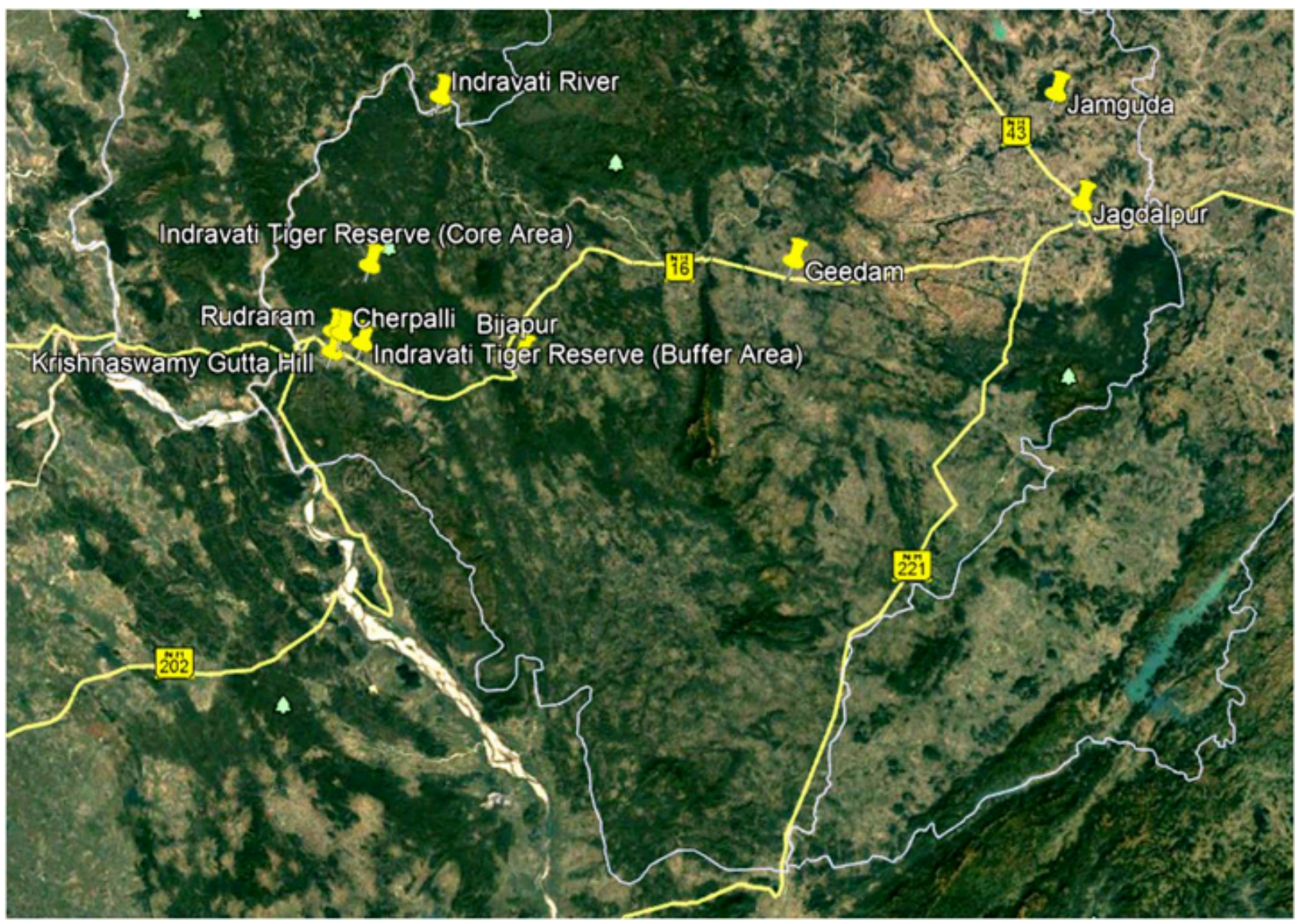

Image 1. Google Earth map of vulture sighting locations in Bastar and Bijapur district of southern Chhattisgarh.

Primary food source for both species of vultures are carcasses of Wild Asian Buffalo, Indian Bison, Nilgai, Blackbuck, Chausinga, Sambar, Chital, Indian Muntjac, Indian Spotted Chevrotain, and Wild Boar in reserve forest (Wildlife Officials, pers. comm. 27th July 2020). Both species of vultures in outskirts of reserve forest feed on carcasses/carrion of domesticated bovines.

Estimates of vulture sightings started from 2011 at Jamguda village, with 18 Gyps bengalensis and five Gyps indicus. A single individual was sighted gliding and soaring in 2015 at Bastar village of Bastar district of southern Chhattisgarh. In 2016, four Gyps bengalensis were sighted at Cherpalli in the Bijapur district. In 2020, frequent sighting of vultures were encounter at various locations in the Bijapur; 13 Gyps bengalensis and 12 Gyps indicus were sighted at Indravati Tiger Reserve (Buffer Area). More and regular sightings were recorded in Rudraram; 30-35 individuals of Gyps bengalensis and 20-25 individuals of Gyps indicus were sighted at Rudraram and Krishna Swami Gutta hill often referred as nesting-roosting habitat was visited and confirmed. Both species are now exploring six identified scavenging areas and possibly homing range of both species covers Bastar and Bijapur district of southern Chhattisgarh. Rudraram and Krishna Swami Gutta hill are two hot spot for these species. These observations are an indication of population recovery of both Gyps bengalensis and Gyps indicus. This sighting result as seen from the logarithmic trend lines in the graph is in conformity with the surveys conducted in 2011 by Prakash and his research team. The population of vulture species remains low, but the decline has slowed and may even have reversed for Gyps bengalensis in India (Prakash et al. 2012).

In recent times vultures have been sighted in good numbers, often in the outskirts of remote villages surrounded with dense trees, higher cliffs and flattops on higher rocky hills, particularly near protected areas and far from urbanization. These habitats must have served as last refuges for those few vultures that survived the Diclofenac era. The factors contributing to the recovery of vulture population in Bastar and Bijapur district are:

a) Conducive habitable places for resting and breeding in Bijapur district, is the first and foremost 

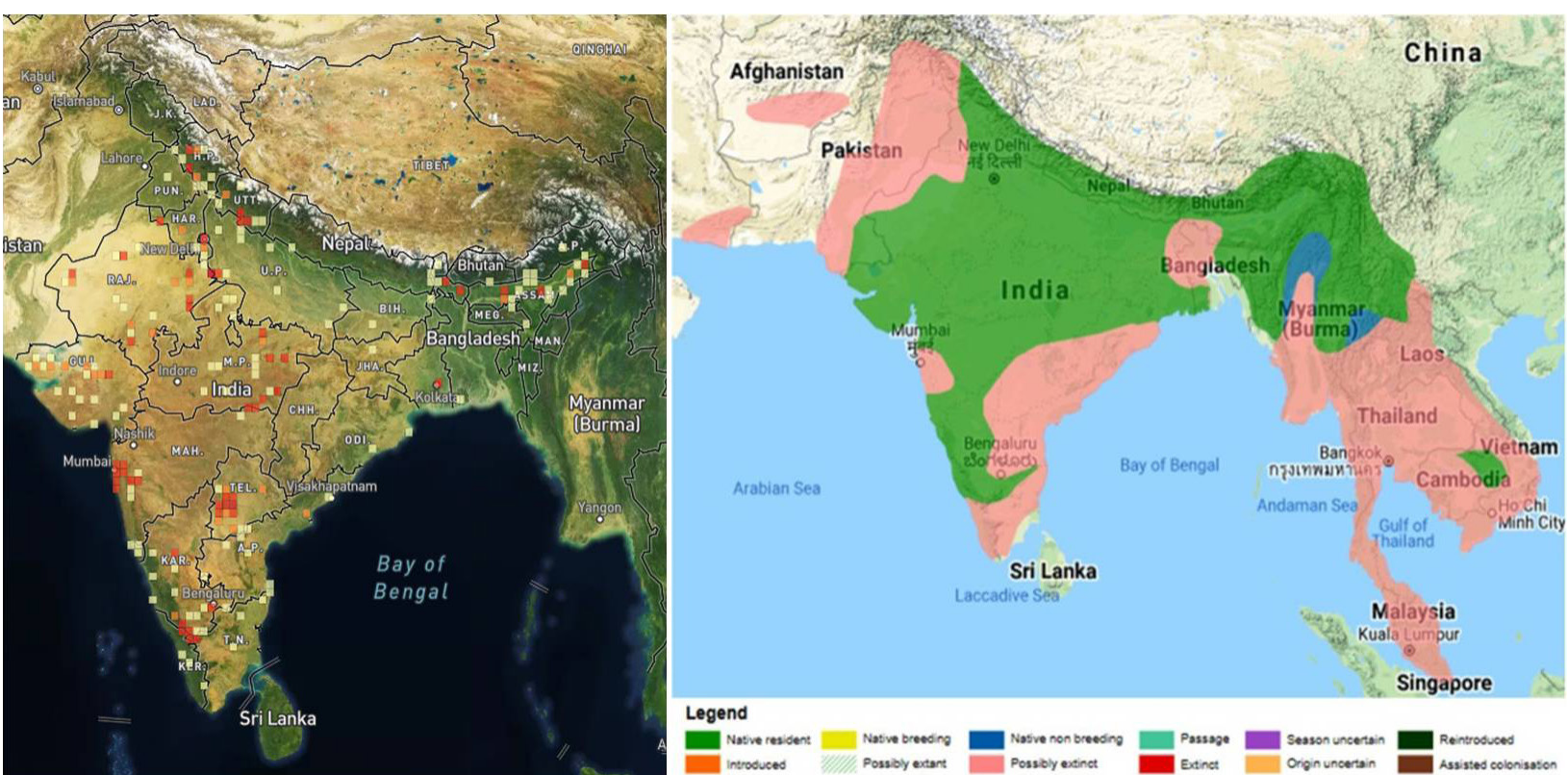

(A) Source: India Biodiversity

(B) Source: BirdLife International 2021

https://indiabiodiversity.org/biodiv/species/show/239129 [Accessed date Jan 7, 2021]

Image 2. A-Map of India showing no record of Gyps bengalensis in Chhattisgarh | B-Map of India showing no records of Gyps bengalensis in southern Chhattisgarh.

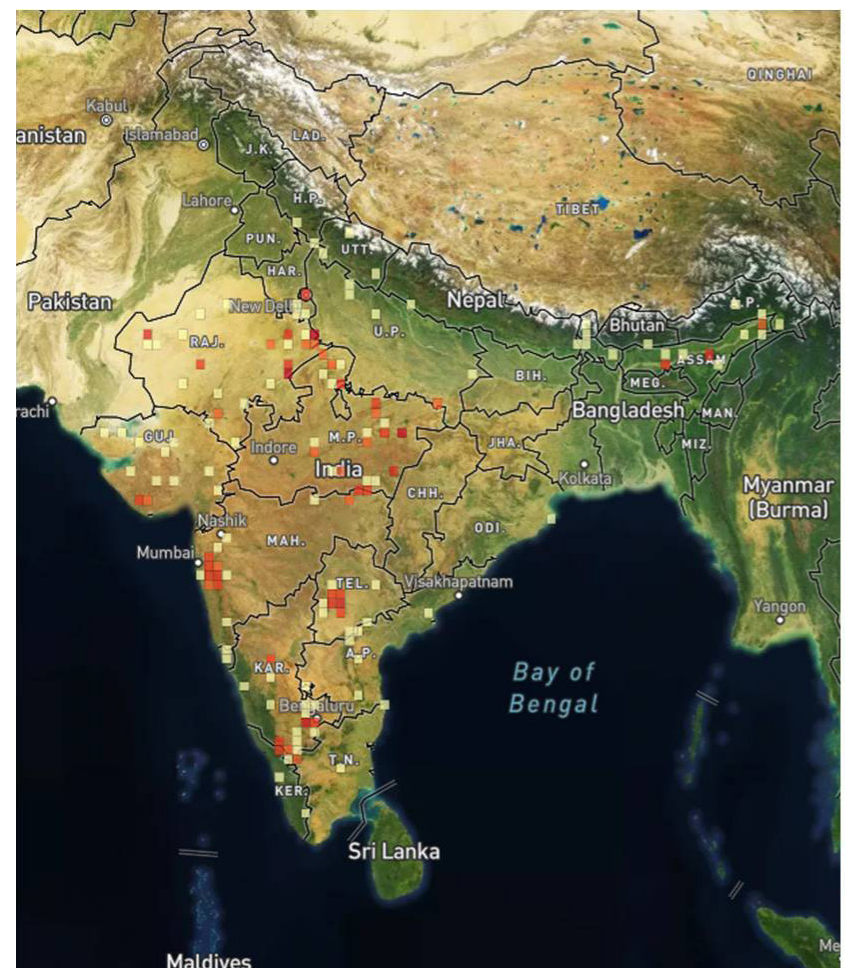

(A) Source: India Biodiversity https://indiabiodiversity.org/species/show/239132 [Accessed date Jan 7, 2021]

Image 3. A-Map of India showing no record of Gyps indicus in Chhattisgarh | B-Map of India showing records of Gyps indicus in Bijapur and Bastar districts of Chhattisgarh.

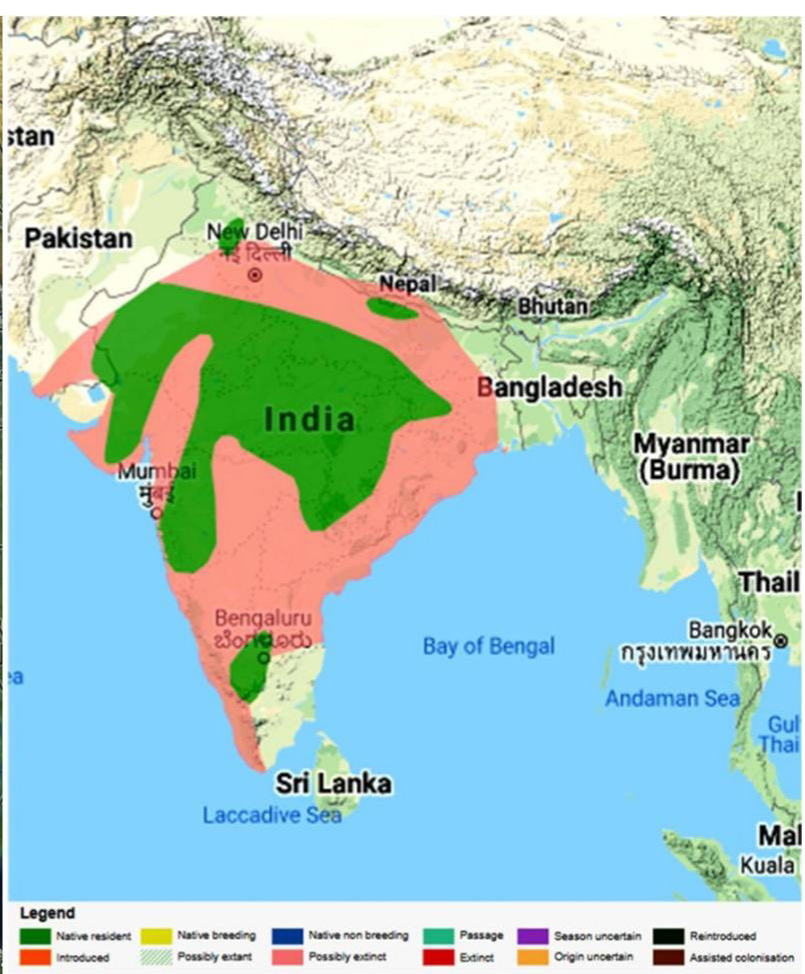

(B) Source: BirdLife International 2021 
important factor for survival and population recovery of vultures. The numbers of vultures were so low that not a single sighting report from this areas exists from 2005-2011 (Image 2 and 3 except for Gyps indicus by BirdLife International).

b) Availability of adequate dead wildlife carcasses in these wild habitats (Indravati Tiger Reserve and Kanger Valley Tiger Reserve) likely sustained the decimated vulture population. Forest staff confirm that mortality of wild animals due to natural factors in protected areas is sufficient to sustain present vulture population. Carcasses of wild beasts and feral domesticated animals in the protected areas and peripheral remote village areas are generally free of Diclofenac contamination. This has ensured a safe and continuous source of food, but vigilance against misuse of Diclofenac is necessary to ensure conservation and recovery of vulture populations.

c) The ban on veterinary use of Diclofenac (i.e., from May 2006 till date) by the Indian Government might had a positive impact on recovery of vulture population, as witnessed in Bastar and Bijapur districts of southern Chhattisgarh. Two years after the ban, 1,150 of 1,251 liver samples from livestock carcasses collected across India between August 2007 and June 2008 were negative (Saini et al. 2012). Similarly, Cuthbert et al. (2011) reported that the concentration of diclofenac before and soon after the ban was $10.8-10.7 \%$, but had dropped to $6.5 \%$ in 31 months after the implementation of the ban, leading to a drop in the annual death rates of vultures from $80 \%$ to $18 \%$.

d) Traditional practises of disposing off dead bovines in designated communal sites in rural villages. An

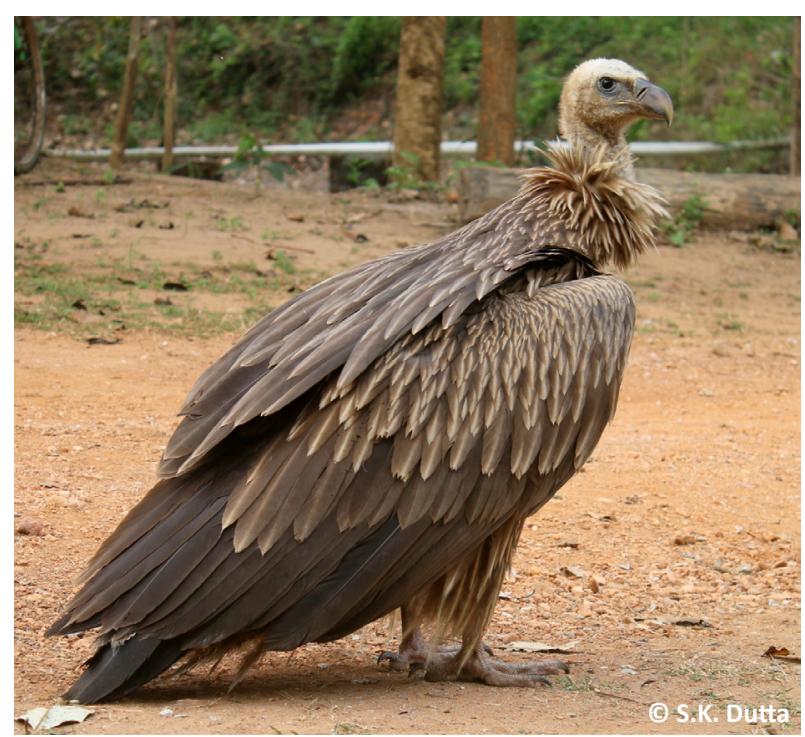

Image 4. Himalayan Griffon Gyps himalayensis. average of 10 bovines (i.e., 2-3 per month) are disposed in each village during the dry season, and 4-5 (i.e., 1-2 per month) in the wet and cold seasons. This is an important contributing factor for recent sightings of vultures in Bastar and Bijapur district.

The southern Chhattisgarh region is possibly a migratory route of vultures. On 04 February 2020, one migrating sub-adult Himalayan Griffon was recorded in Geedam village of Dantewada district. The repeated sightings of vultures around the same area and their nesting in the Krishna Swami Gutta hill is an opportunity to plan for the conservation of both species Gyps bengalensis and Gyps indicus vultures in India.

\section{Suggestions}

1. The traditional practise of disposing off dead bovines free of diclofenac contamination should be promoted in other designated communal sites instead of burying - to ensure a safe, constant source of food enabling vulture populations to grow further.

2. Camera traps should be fixed in nesting, roosting and scavenging areas to monitor inter and intra species interactions.

3. Long-term vulture monitoring projects should be undertaken; fitting of satellite telemeters on discrete population in roosting and scavenging areas for understanding movements, other parameters and physical challenges due to vast home range.

4. Krishna Swami Gutta hill must be designated as a 'Vulture Sanctuary' to protect the nesting sites of these vultures.

5. Vigilance and legal actions should be adopted on any diclofenac use in veterinary. Sensitization of chemists and drug associations, pharmacists, veterinary councils and farmers should be undertaken along

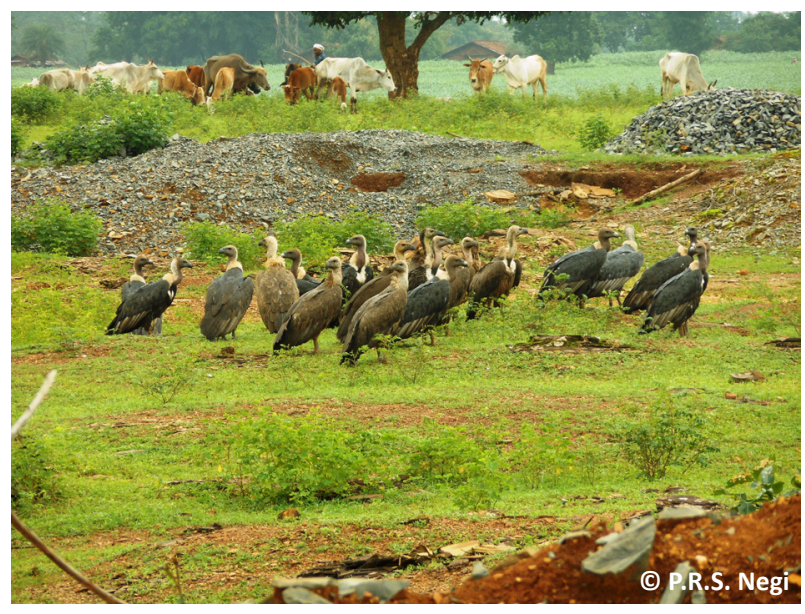

Image 5. Vulture sighting at Jamguda, Bastar. 


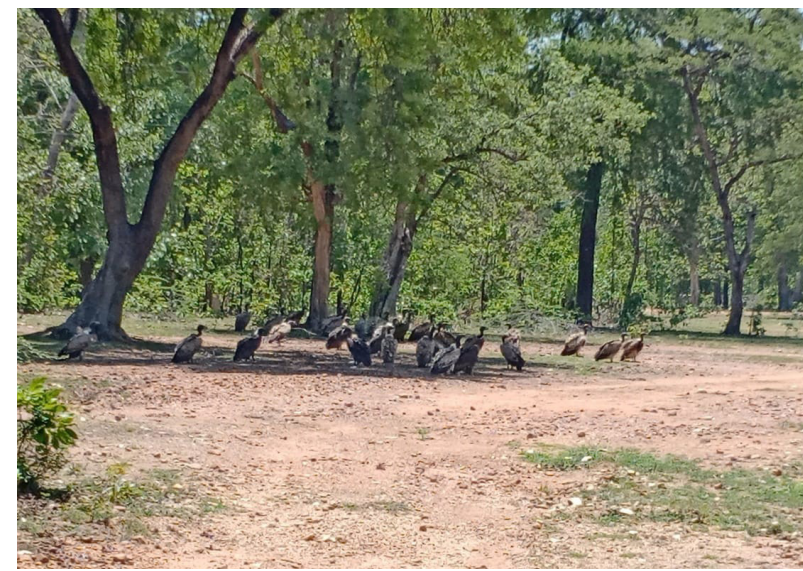

Image 6. Vulture sighting at Indravati Tiger Reserve, Bijapur.

(C) Forest Officials of Indravati Tiger Reserve.

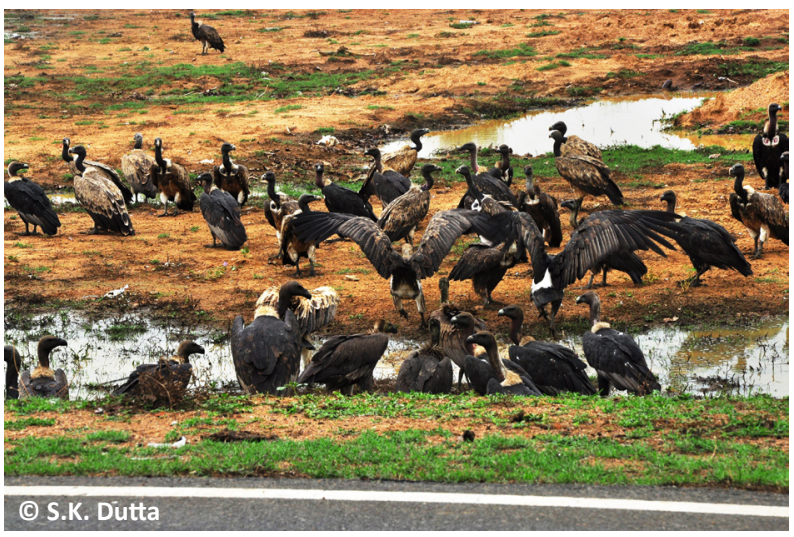

Image 7. Vulture sighting at Rudraram, Bijapur.

with understanding the implications of substitute of diclofenac drug in veterinary use. Lead contamination is also a serious concern for vultures and need to be monitored for future of vultures recovery.

\section{REFERENCES}

Birdlife International (2021). Species factsheet: Gyps bengalensis and Gyps indicus. Downloaded from http://birdlife.org

Birdlife International (2021). IUCN Red List for birds. Downloaded from http://birdlife.org

Chhattisgarh State District-wise Cattle population (2019). $20^{\text {th }}$ Livestock Census, 1-7. http://agriportal.cg.nic.in/ahd/PDF_ common/census20th/2_Districtwise_Animal_population_20th_ LSC.pdf

Cuthbert, R., M.A. Taggart, V. Prakash, M. Saini, D. Swarup, S. Upreti, R. Mateo, S.S. Chakraborty, P. Deori \& R.E. Green (2011). Effectiveness of action in India to reduce exposure of Gyps vultures to the toxic veterinary drug Diclofenac. PLoS One 6(5): e19069. https://doi.org/10.1371/journal.pone.0019069

Ghosh, S., R.S. Basu, B.K. Datta \& A.K. Sett (2008). Fauna of Madhya Pradesh (including Chhattisgarh), State Fauna Series, 15 (Part 2), Aves. Zoological Survey of India, Kolkata, 152pp.

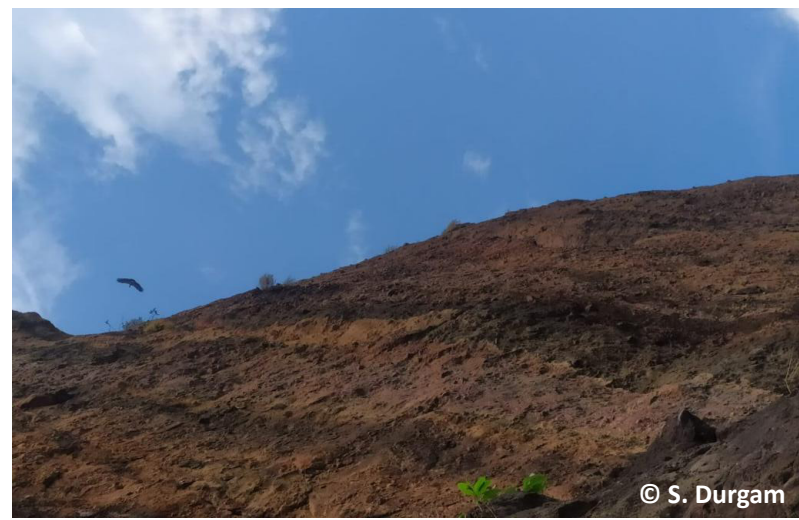

Image 8. Vulture sighting at Krishna Swamy Gutta Hill, Bijapur.

Green, R.E., I. Newton, S. Shultz, A.A. Cunningham, M. Gilbert, D.J. Pain \& V. Prakash (2004). Diclofenac poisoning as a cause of vulture population declines across the Indian Subcontinent. Journal of Applied Ecology 41(5): 793-800.

Grimmett, R., C. Inskipp \& T. Inskipp (2011). Birds of the Indian Subcontinent, Christopher Helm, London, 528pp.

Indian State of Forest Report (2019). 11.5 Chhattisgarh, 44-53. http:// www.indiaenvironmentportal.org.in/files/file/isfr-fsi-vol2.pdf

Naoroji, R. (2011). Birds of Prey of the Indian Subcontinent. Om Books International, New Delhi, 692pp.

Prakash, V., D.J. Pain, A.A. Cunningham, P.F. Donald, N. Prakash, A. Verma, R. Gargi, S. Sivakumar \& A.R. Rahmani (2003). Catastrophic collapse of Indian white-backed Gyps bengalensis and long-billed Gyps indicus vulture populations. Biological Conservation 109: 381-390.

Prakash, V., M.C. Bishwakarma, A. Chaudhary, R. Cuthbert, R. Dave, M. Kulkarni, S. Kumar, K. Paudel, S. Ranade, R. Shringarpure \& R.E. Green (2012). The population decline of Gyps vultures in India and Nepal has slowed since veterinary use of diclofenac was banned. PLoS One 7(11): e49118. https://doi.org/10.1371/journal. pone.0049118

Saini, M., M.A. Taggart, D. Knopp, S. Upreti, D. Swarup, A. Das, P.K. Gupta, R. Niessner, V. Prakash, R. Mateo \& R.J. Cuthbert (2012). Detecting Diclofenac in livestock carcasses in India with an ELISA: a tool to prevent widespread vulture poisoning. Environmental Pollution 160(1): 11-16. https://doi.org/10.1016/j. envpol.2011.09.011

Unique Identification Aadhar India. Updated 31 May 2019. http:// www.populationu.com/in/chhattisgarh-population

Author details: DR. S.K. DUTTA, Assistant Professor in the Department of Zoology, Govt. P.G. College, Jagdalpur, Bastar, Chhattisgarh. His field of research interest is animal diversity, ecology of amphibians and herpetofauna. In recent years, he avidly explores the avifauna diversity in southern Chhattisgarh. Guide students in their project works. DR. M. KHAN, Assistant Professor in the Department of Zoology, Kalahandi University, Manikya Vihar, Bhawanipatna, Kalahandi, Odisha. Research interest is Cetacean diversity, population, behaviour, ecology of aquatic ecosystem, ecosystem services, Fish and Fisheries. Experienced in Crocodiles, Marine turtles and Migratory birds research. Guide undergraduate students in project work. DR. P.R.S. NEGI is a Veterinary Surgeon in Bastar Veterinary Hospital, Bastar, Chhattisgarh and dedicated to animals health issues with a passion for wildlife. His research interest is avifaunal diversity, captive/pet animal nutrition, health issues and monitoring prevalence zoonotic diseases. MR. S. DURGAM is a student of M. Sc Zoology from Govt. P.G. College, Jagdalpur, Bastar, Chhattisgarh and a resident of Bijapur district. He pursued his research-intern in this work. Has developed research interest to continue this study and survey on Vultures in Bijapur District of Chhattisgarh. Ms. S. DUTTA is an undergraduate student from Institute for Excellence in Higher Education, Bhopal, Madhya Pradesh. She has keen passion and research aptitude for wildlife and conservation. She monitors avifaunal diversity of Bastar District. 
Dr. John Noyes, Natural History Museum, London, UK

Dr. Albert G. Orr, Griffith University, Nathan, Australia

Dr. Sameer Padhye, Katholieke Universiteit Leuven, Belgium

Dr. Nancy van der Poorten, Toronto, Canada

Dr. Kareen Schnabel, NIWA, Wellington, New Zealand

Dr. R.M. Sharma, (Retd.) Scientist, Zoological Survey of India, Pune, India

Dr. Manju Siliwal, WILD, Coimbatore, Tamil Nadu, India

Dr. G.P. Sinha, Botanical Survey of India, Allahabad, India

Dr. K.A. Subramanian, Zoological Survey of India, New Alipore, Kolkata, India

Dr. P.M. Sureshan, Zoological Survey of India, Kozhikode, Kerala, India

Dr. R. Varatharajan, Manipur University, Imphal, Manipur, India

Dr. Eduard Vives, Museu de Ciències Naturals de Barcelona, Terrassa, Spain

Dr. James Young, Hong Kong Lepidopterists' Society, Hong Kong

Dr. R. Sundararaj, Institute of Wood Science \& Technology, Bengaluru, India

Dr. M. Nithyanandan, Environmental Department, La Ala Al Kuwait Real Estate. Co. K.S.C.,

Kuwait

Dr. Himender Bharti, Punjabi University, Punjab, India

Mr. Purnendu Roy, London, UK

Dr. Saito Motoki, The Butterfly Society of Japan, Tokyo, Japan

Dr. Sanjay Sondhi, TITLI TRUST, Kalpavriksh, Dehradun, India

Dr. Nguyen Thi Phuong Lien, Vietnam Academy of Science and Technology, Hanoi, Vietnam

Dr. Nitin Kulkarni, Tropical Research Institute, Jabalpur, India

Dr. Robin Wen Jiang Ngiam, National Parks Board, Singapore

Dr. Lional Monod, Natural History Museum of Geneva, Genève, Switzerland.

Dr. Asheesh Shivam, Nehru Gram Bharti University, Allahabad, India

Dr. Rosana Moreira da Rocha, Universidade Federal do Paraná, Curitiba, Brasi

Dr. Kurt R. Arnold, North Dakota State University, Saxony, Germany

Dr. James M. Carpenter, American Museum of Natural History, New York, USA

Dr. David M. Claborn, Missouri State University, Springfield, USA

Dr. Kareen Schnabel, Marine Biologist, Wellington, New Zealand

Dr. Amazonas Chagas Júnior, Universidade Federal de Mato Grosso, Cuiabá, Brasil

Mr. Monsoon Jyoti Gogoi, Assam University, Silchar, Assam, India

Dr. Heo Chong Chin, Universiti Teknologi MARA (UiTM), Selangor, Malaysia

Dr. R.J. Shiel, University of Adelaide, SA 5005, Australia

Dr. Siddharth Kulkarni, The George Washington University, Washington, USA

Dr. Priyadarsanan Dharma Rajan, ATREE, Bengaluru, India

Dr. Phil Alderslade, CSIRO Marine And Atmospheric Research, Hobart, Australia

Dr. John E.N. Veron, Coral Reef Research, Townsville, Australia

Dr. Daniel Whitmore, State Museum of Natural History Stuttgart, Rosenstein, Germany.

Dr. Yu-Feng Hsu, National Taiwan Normal University, Taipei City, Taiwan

Dr. Keith V. Wolfe, Antioch, California, USA

Dr. Siddharth Kulkarni, The Hormiga Lab, The George Washington University, Washington,

D.C., USA

Dr. Tomas Ditrich, Faculty of Education, University of South Bohemia in Ceske

Budejovice, Czech Republic

Dr. Mihaly Foldvari, Natural History Museum, University of Oslo, Norway

Dr. V.P. Uniyal, Wildlife Institute of India, Dehradun, Uttarakhand 248001, India

Dr. John T.D. Caleb, Zoological Survey of India, Kolkata, West Bengal, India

Dr. Priyadarsanan Dharma Rajan, Ashoka Trust for Research in Ecology and the Environment

(ATREE), Royal Enclave, Bangalore, Karnataka, India

\section{Fishes}

Dr. Neelesh Dahanukar, IISER, Pune, Maharashtra, India

Dr. Topiltzin Contreras MacBeath, Universidad Autónoma del estado de Morelos, México

Dr. Heok Hee Ng, National University of Singapore, Science Drive, Singapore

Dr. Rajeev Raghavan, St. Albert's College, Kochi, Kerala, India

Dr. Robert D. Sluka, Chiltern Gateway Project, A Rocha UK, Southall, Middlesex, UK

Dr. E. Vivekanandan, Central Marine Fisheries Research Institute, Chennai, India

Dr. Davor Zanella, University of Zagreb, Zagreb, Croatia

Dr. A. Biju Kumar, University of Kerala, Thiruvananthapuram, Kerala, India

Dr. Akhilesh K.V., ICAR-Central Marine Fisheries Research Institute, Mumbai Research

Centre, Mumbai, Maharashtra, India

Dr. J.A. Johnson, Wildlife Institute of India, Dehradun, Uttarakhand, India

Amphibians

Dr. Sushil K. Dutta, Indian Institute of Science, Bengaluru, Karnataka, India

Dr. Annemarie Ohler, Muséum national d'Histoire naturelle, Paris, France

\section{Reptiles}

Dr. Gernot Vogel, Heidelberg, Germany

Dr. Raju Vyas, Vadodara, Gujarat, India

Dr. Pritpal S. Soorae, Environment Agency, Abu Dubai, UAE.

Prof. Dr. Wayne J. Fuller, Near East University, Mersin, Turkey

Prof. Chandrashekher U. Rivonker, Goa University, Taleigao Plateau, Goa. India

Dr. S.R. Ganesh, Chennai Snake Park, Chennai, Tamil Nadu, India

Dr. Himansu Sekhar Das, Terrestrial \& Marine Biodiversity, Abu Dhabi, UAE
Birds

Dr. Hem Sagar Baral, Charles Sturt University, NSW Australia

Dr. Chris Bowden, Royal Society for the Protection of Birds, Sandy, UK

Dr. Priya Davidar, Pondicherry University, Kalapet, Puducherry, India

Dr. J.W. Duckworth, IUCN SSC, Bath, UK

Dr. Rajah Jayapal, SACON, Coimbatore, Tamil Nadu, India

Dr. Rajiv S. Kalsi, M.L.N. College, Yamuna Nagar, Haryana, India

Dr. V. Santharam, Rishi Valley Education Centre, Chittoor Dt., Andhra Pradesh, India

Dr. S. Balachandran, Bombay Natural History Society, Mumbai, India

Mr. J. Praveen, Bengaluru, India

Dr. C. Srinivasulu, Osmania University, Hyderabad, India

Dr. K.S. Gopi Sundar, International Crane Foundation, Baraboo, USA

Dr. Gombobaatar Sundev, Professor of Ornithology, Ulaanbaatar, Mongolia

Prof. Reuven Yosef, International Birding \& Research Centre, Eilat, Israel

Dr. Taej Mundkur, Wetlands International, Wageningen, The Netherlands

Dr. Carol Inskipp, Bishop Auckland Co., Durham, UK

Dr. Tim Inskipp, Bishop Auckland Co, Durham, UK

Dr. V. Gokula, National College, Tiruchirappalli, Tamil Nadu, India

Dr. Arkady Lelej, Russian Academy of Sciences, Vladivostok, Russia

Dr. Simon Dowell, Science Director, Chester Zoo, UK

Dr. Mário Gabriel Santiago dos Santos, Universidade de Trás-os-Montes e Alto Douro,

Quinta de Prados, Vila Real, Portugal

Dr. Grant Connette, Smithsonian Institution, Royal, VA, USA

Dr. M. Zafar-ul Islam, Prince Saud Al Faisal Wildlife Research Center, Taif, Saudi Arabia

Mammals

Dr. Giovanni Amori, CNR - Institute of Ecosystem Studies, Rome, Italy

Dr. Anwaruddin Chowdhury, Guwahati, India

Dr. David Mallon, Zoological Society of London, UK

Dr. Shomita Mukherjee, SACON, Coimbatore, Tamil Nadu, India

Dr. Angie Appel, Wild Cat Network, Germany

Dr. P.O. Nameer, Kerala Agricultural University, Thrissur, Kerala, India

Dr. Ian Redmond, UNEP Convention on Migratory Species, Lansdown, UK

Dr. Heidi S. Riddle, Riddle's Elephant and Wildlife Sanctuary, Arkansas, USA

Dr. Karin Schwartz, George Mason University, Fairfax, Virginia.

Dr. Lala A.K. Singh, Bhubaneswar, Orissa, India

Dr. Mewa Singh, Mysore University, Mysore, India

Dr. Paul Racey, University of Exeter, Devon, UK

Dr. Honnavalli N. Kumara, SACON, Anaikatty P.O., Coimbatore, Tamil Nadu, India

Dr. Nishith Dharaiya, HNG University, Patan, Gujarat, India

Dr. Spartaco Gippoliti, Socio Onorario Società Italiana per la Storia della Fauna "Giuseppe

Altobello", Rome, Italy

Dr. Justus Joshua, Green Future Foundation, Tiruchirapalli, Tamil Nadu, India

Dr. H. Raghuram, The American College, Madurai, Tamil Nadu, India

Dr. Paul Bates, Harison Institute, Kent, UK

Dr. Jim Sanderson, Small Wild Cat Conservation Foundation, Hartford, USA

Dr. Dan Challender, University of Kent, Canterbury, UK

Dr. David Mallon, Manchester Metropolitan University, Derbyshire, UK

Dr. Brian L. Cypher, California State University-Stanislaus, Bakersfield, CA

Dr. S.S. Talmale, Zoological Survey of India, Pune, Maharashtra, India

Prof. Karan Bahadur Shah, Budhanilakantha Municipality, Kathmandu, Nepal

Dr. Susan Cheyne, Borneo Nature Foundation International, Palangkaraja, Indonesia

Dr. Hemanta Kafley, Wildlife Sciences, Tarleton State University, Texas, USA

\section{Other Disciplines}

Dr. Aniruddha Belsare, Columbia MO 65203, USA (Veterinary)

Dr. Mandar S. Paingankar, University of Pune, Pune, Maharashtra, India (Molecular)

Dr. Jack Tordoff, Critical Ecosystem Partnership Fund, Arlington, USA (Communities)

Dr. Ulrike Streicher, University of Oregon, Eugene, USA (Veterinary)

Dr. Hari Balasubramanian, EcoAdvisors, Nova Scotia, Canada (Communities)

Dr. Rayanna Hellem Santos Bezerra, Universidade Federal de Sergipe, São Cristóvão, Brazil

Dr. Jamie R. Wood, Landcare Research, Canterbury, New Zealand

Dr. Wendy Collinson-Jonker, Endangered Wildlife Trust, Gauteng, South Africa

Dr. Rajeshkumar G. Jani, Anand Agricultural University, Anand, Gujarat, India

Dr. O.N. Tiwari, Senior Scientist, ICAR-Indian Agricultural Research Institute (IARI), New

Delhi, India

Dr. L.D. Singla, Guru Angad Dev Veterinary and Animal Sciences University, Ludhiana, India

Dr. Rupika S. Rajakaruna, University of Peradeniya, Peradeniya, Sri Lanka

Dr. Bahar Baviskar, Wild-CER, Nagpur, Maharashtra 440013, India

Reviewers 2018-2020

Due to pausity of space, the list of reviewers for $2018-2020$ is available online.

The opinions expressed by the authors do not reflect the views of the Journal of Threatened Taxa, Wildlife Information Liaison Development Society, Zoo Outreach Organization, or any of the partners. The journal, the publisher, the host, and the partners are not responsible for the accuracy of the political boundaries shown in the maps by the authors.

Journal of Threatened Taxa is indexed/abstracted in Bibliography of Systematic Mycology, Biological Abstracts, BIOSIS Previews, CAB Abstracts, EBSCO, Google Scholar, Index Copernicus, Index Fungorum, JournalSeek, National Academy of Agricultural Sciences, NewJour, OCLC WorldCat, SCOPUS, Stanford University Libraries, Virtual Library of Biology, Zoological Records.

NAAS rating (India) 5.64
Print copies of the Journal are available at cost. Write to:

The Managing Editor, JoTT,

c/o Wildlife Information Liaison Development Society,

No. 12, Thiruvannamalai Nagar, Saravanampatti - Kalapatti Road,

Saravanampatti, Coimbatore, Tamil Nadu 641035, India

ravi@threatenedtaxa.org 


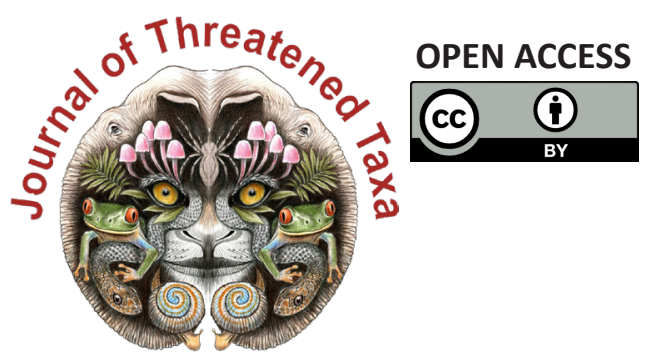

www.threatenedtaxa.org

The Journal of Threatened Taxa (JoTT) is dedicated to building evidence for conservation globally by publishing peer-reviewed articles online every month at a reasonably rapid rate at www.threatenedtaxa.org. All articles published in JoTT are registered under Creative Commons Attribution 4.0 International License unless otherwise mentioned. JoTT allows allows unrestricted use, reproduction, and distribution of articles in any medium by providing adequate credit to the author(s) and the source of publication.

ISSN 0974-7907 (Online) I ISSN $0974-7893$ (Print)

\section{November 2021 | Vol. 13 | No. 13 | Pages: 19887-20142 \\ Date of Publication: 26 November 2021 (Online \& Print) DOI: 10.11609/jott.2021.13.13.19887-20142}

\section{Article}

An inventory of geometrid moths (Lepidoptera: Geometroidea: Geometridae) of KalakadMundanthurai Tiger Reserve, India

- Geetha Iyer, Dieter Stüning \& Sanjay Sondhi, Pp. 19887-19920

\section{Communications}

Roadkills of Lowland Tapir Tapirus terrestris (Mammalia: Perissodactyla: Tapiridae) in one of its last refuges in the Atlantic Forest

- Aureo Banhos, Andressa Gatti, Marcelo Renan de Deus Santos, Leonardo Merçon,

Ilka Westermeyer, Natália Carneiro Ardente, Luis Francisco Oliveira Pereira Gonzaga, Lucas Mendes Barreto, Lucas Damásio, Tomas Lima Rocha, Vitor Roberto Schettino, Renata Valls, Helena Godoy Bergallo, Marcos Vinicius Freitas Silva, Athelson Stefanon Bittencourt, Danielle de Oliveira Moreira \& Ana Carolina Srbek-Araujo, Pp. 19921-19929

Scientific contributions and learning experiences of citizen volunteers with a small cat project in Sanjay Gandhi National Park, Mumbai, India

- Shomita Mukherjee, R. Nandini, P.V. Karunakaran \& Nayan Khanolkar, Pp. 19930-19936

Seasonal food preferences and group activity pattern of Blackbuck Antilope cervicapra (L., 1758) (Mammalia: Cetartiodactyla: Bovidae) in a semi-arid region of western Haryana, India

- Vikram Delu, Dharambir Singh, Sumit Dookia, Priya \& Kiran, Pp. 19937-19947

Studies on the habitats of Grey Francolin Francolinus pondicerianus (J.F. Gmelin, 1789) (Galliformes: Phasianidae) in northern districts of Tamil Nadu, India

- M. Pandian, Pp. 19948-19955

Recovery of vulture population in roosting and scavenging areas of Bastar and Bijapur, Chhattisgarh, India

- Sushil Kumar Dutta, Muntaz Khan, P.R.S. Nagi, Santosh Durgam \& Surabhi Dutta, Pp. 19956-19963

A geographical assessment of Chariganga and Arpara Beel (wetlands) of Nadia, West Bengal as a habitat of wetland birds

- Mehedi Hasan Mandal, Arindam Roy \& Giyasuddin Siddique, Pp. 19964-19975

Phenotypic plasticity in Barilius vagra (Hamilton, 1822) (Teleostei: Danionidae) from two geographically distinct river basins of Indian Himalaya

- Sumit Kumar, Sharali Sharma \& Deepak Singh, Pp. 19976-19984

Taxonomic notes, a new species, and a key to Indian species of the click beetle genus Cryptalaus Ôhira, 1967 (Coleoptera: Elateridae: Agrypninae)

- Harshad Parekar \& Amol Patwardhan, Pp. 19985-19999

Niche overlap of benthic macrofauna in a tropical estuary: diurnal variation

- Mário Herculano de Oliveira, Lidiane Gomes de Lima, Caroline Stefani da Silva Lima, Jéssica de Oliveira Lima Gomes, Franciely Ferreira Paiva, Graciele de Barros, Carlinda Railly Medeiros \& Joseline Molozzi, Pp. 20000-20010

Diversity of aquatic insects and biomonitoring of water quality in the upper Ganga River, a Ramsar site: a preliminary assessment

- Kritish De, Arkojyoti Sarkar, Kritika Singh, Virendra Prasad Uniyal, Jeyaraj Antony Johnson \& Syed Ainul Hussain, Pp. 20011-20018

Patterns of forest cover loss in the terrestrial Key Biodiversity Areas in the Philippines: critical habitat conservation priorities

- Bernard Peter O. Daipan, Pp. 20019-20032

The woody flora of Shettihalli Wildlife Sanctuary, central Western Ghats of Karnataka, India - A checklist

- Kanda Naveen Babu, Kurian Ayushi, Vincy K. Wilson, Narayanan Ayyappan \&

Narayanaswamy Parthasarathy, Pp. 20033-20055

Reproductive biology of Ophiorrhiza caudata C.E.C.Fisch. (Rubiaceae), an endemic and endangered creeping perennial herb of the Western Ghats, India

- Maria Theresa, Appukuttan Kamalabai Sreekala \& Jayalakshmi Mohanlal, Pp. 20056-20065
Short Communications

Successful rescue, medical management, rehabilitation, and translocation of a Red Panda Ailurus fulgens (Mammalia: Carnivora: Ailuridae) in Arunachal Pradesh, India - Jahan Ahmed, Sorang Tadap, Millo Tasser, Koj Rinya, Nekibuddin Ahmed \& Sunil Kyarong, Pp. 20066-20071

A rare photographic record of Eurasian Otter Lutra lutra with a note on its habitat from the Bhagirathi Basin, western Himalaya, India

- Ranjana Pal, Aashna Sharma, Vineet Kumar Dubey, Tapajit Bhattacharya, Jeyaraj Antony Johnson, Kuppusamy Sivakumar \& Sambandam Sathyakumar, Pp. 20072-20077

The first record of Medog Gliding Frog Rhacophorus translineatus Wu, 1977 (Anura: Rhacophoridae) from Chhukha District, Bhutan

- Sonam Lhendup \& Bal Krishna Koirala, Pp. 20078-20083

First record of a freshwater crab, Maydelliathelphusa masoniana (Henderson, 1893) (Decapoda: Brachyura: Gecarcinucidae) from West Bengal, India

- Ram Krishna Das, Pp. 20084-20089

Butterflies of Amrabad Tiger Reserve, Telangana, India

- Deepa Jaiswal, B. Bharath, M. Karuthapandi, Shrikant Jadhav, S. Prabakaran \& S. Rehanuma Sulthana, Pp. 20090-20097

An enumeration of the flowering plants of Kyongnosla Alpine Sanctuary in eastern Sikkim, India

- Sudhansu Sekhar Dash, Subhajit Lahiri \& Ashiho Asoshii Mao, Pp. 20098-20117

A new record of psychrotrophic Paecilomyces formosus (Eurotiales: Ascomycota) from India: morphological and molecular characterization

- Skarma Nonzom \& Geeta Sumbali, Pp. 20118-20123

Notes

Study on incidence and pathology of gastrointestinal parasitic infections in Nilgai Boselaphus tragocamelus in Hisar, Haryana, India

- Maneesh Sharma, B.L. Jangir, D. Lather, G.A. Chandratre, V. Nehra, K.K. Jakhar \& G. Narang, Pp. 20124-20127

An unusual vocalization of Brown Hawk-Owl Ninox scutulata (Raffles, 1822) (Aves:

Strigiformes: Strigidae) recorded from Kerala, India

- Riju P. Nair \& Shine Raj Tholkudiyil, Pp. 20128-20129

New distribution data on the genus Maripanthus Maddison, 2020 (Araneae: Salticidae) from southern India

- A. Asima, John T.D. Caleb, Dhruv A. Prajapati \& G. Prasad, Pp. 20130-20132

On the IUCN status of Boesenbergia albolutea and B. rubrolutea (Zingiberaceae) and typification of $B$. rubrolutea

- K. Aishwarya \& M. Sabu, Pp. 20133-20135

New records of mass seeding Cephalostachyum latifolium Munro (Poaceae) along the midelevation broadleaved forest of Sarpang district, Bhutan

- Jigme Tenzin, Sangay Nidup \& Dago Dorji, Pp. 20136-20139

Response

If habitat heterogeneity is effective for conservation of butterflies in urban landscapes of Delhi, India?' Unethical publication based on data manipulation

- Sanjay Keshari Das \& Rita Singh, Pp. 20140-20142

Publisher \& Host
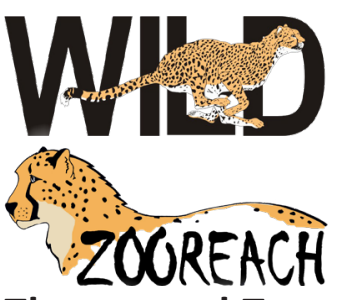

Threatened Taxa 